\title{
Wpływ rezydualnego nasycenia gazem poniżej stwierdzonego kontaktu woda-gaz na proces eksploatacji złoża
}

\section{Impact of residual gas saturation below the specified water-gas contact on the production process}

\author{
Tomasz Tuczyński ${ }^{1,3}$, Daniel Podsobiński ${ }^{2,3}$, Jerzy Stopa ${ }^{3}$ \\ ${ }^{1}$ PGNiG Upstream Norway AS \\ ${ }^{2}$ PGNiG S.A. Oddział Geologii i Eksploatacji w Warszawie \\ ${ }^{3}$ Akademia Górniczo-Hutnicza im. St. Staszica w Krakowie
}

\begin{abstract}
STRESZCZENIE: Złoża gazu ziemnego przez miliony lat poddawane były działaniu rozmaitych czynników geologicznych, które wpływają na ich ostateczny stan i kształt. Zdarza się, że po pewnym czasie produkcji złoże posiada dodatkową energię oraz większe zasoby gazu, niż spodziewano się pierwotnie. Przyczyną tego może być rezydualne nasycenie gazem poniżej wyznaczonego kontaktu woda-gaz, które nie zostało uwzględnione we wcześniejszych analizach. Nieuwzględnienie rezydualnej strefy węglowodorów może prowadzić do błędnych wniosków na temat zasobów, wydobycia ze złoża oraz czasu zawodnienia otworów produkcyjnych. W niniejszej pracy przeprowadzono analizę wpływu rezydualnej strefy gazowej występującej poniżej konturu woda-gaz na proces produkcji z rzeczywistego złoża gazowo-kondensatowego. Obliczenia zostały wykonane za pomocą dynamicznego modelu złożowego z użyciem komercyjnego symulatora numerycznego Eclipse. Na potrzeby pracy zostało wykonanych 6 modeli dynamicznych, na podstawie których przeprowadzono analizę wpływu na skumulowane wydobycie gazu i wody parametrów takich jak krytyczne nasycenie gazem w strefie rezydualnej oraz objętość warstwy wodonośnej. Na podstawie przedstawionego przykładu wielkość całkowitych zasobów geologicznych po uwzględnieniu strefy rezydualnej wzrosła o około 19\%. Oddziaływanie rezydualnej strefy gazowej na wielkość wydobycia gazu nie jest jednak jednoznaczne i jej obecność może wpłynąć zarówno pozytywnie, jak i negatywnie na wielkość wydobycia gazu. Wielkość oraz rodzaj wpływu wynikającego z występowania strefy rezydualnej są bezpośrednio związane z warunkami geologiczno-złożowymi występującymi na danym złożu oraz z samym sposobem prowadzenia eksploatacji. Otrzymane rezultaty wskazują również, że rezydualna strefa gazowa może wpływać na czas zawodnienia otworów produkcyjnych oraz na wielkość wydobycia wody złożowej.
\end{abstract}

Słowa kluczowe: rezydualna strefa nasycenia gazem, krytyczne nasycenie gazem, dynamiczny model złoża, wodnonaporowy system energetyczny złoża.

\begin{abstract}
Natural gas fields over millions of years are exposed to various geological factors that affect their final state and shape. It happens that after some time of production, the reservoir has additional energy and greater gas resources than originally expected. The reason for this may be residual gas saturation below the specified gas-water contact, which has not been included in previous analyzes. Disregarding the residual hydrocarbon zone may lead to erroneous conclusions about resources, recovery factors and water breakthrough time. In this paper the residual gas zone impact on the production process from a real gas-condensate reservoir has been analyzed. The calculations were conducted using a dynamic reservoir model created in Eclipse numerical simulator. For the purpose of the analysis, 6 dynamic models were made. On their basis, an analysis of the impact on cumulative gas and water production was carried out for parameters such as: critical gas saturation in the residual zone and volume of aquifer. Based on the presented example, the overall gas initial in place after taking into account the residual zone has increased about $19 \%$. However, the impact of the residual gas zone on cumulative gas production is not clear-cut and its presence can have a positive as well as negative impact on the cumulative gas production. The size and type of the impact resulting from presence of the residual gas zone is directly related to the geological and reservoir conditions in the given reservoir and the way of production operation. The obtained results indicate also that the residual gas zone may affect the water breakthrough time in production wells as well as total volume of produced water.
\end{abstract}

Key words: residual gas zone, critical gas saturation, dynamic reservoir model, waterdrive mechanism

Autor do korespondencji: D. Podsobiński, e-mail: daniel.podsobinski@pgnig.pl

Artykuł nadesłano do Redakcji: 07.05.2020 r. Zatwierdzono do druku: 28.08.2020 r. 


\section{Wprowadzenie}

Złoża gazu ziemnego przez miliony lat poddawane były działaniu rozmaitych czynników geologicznych wpływających na ich ostateczny stan, który jest stwierdzony otworami poszukiwawczymi, rozpoznawczymi, a na koniec - produkcyjnymi. Zdarza się, że po pewnym czasie produkcji złoże posiada dodatkową energię oraz większe zasoby gazu, niż spodziewano się pierwotnie. Przyczyną tego może być rezydualne nasycenie gazem poniżej wyznaczonego kontaktu woda-gaz, które nie zostało uwzględnione we wcześniejszych analizach. Wiele złóż ze stwierdzonym rezydualnym nasyceniem gazem poniżej kontaktu z wodą znajduje się na Morzu Irlandzkim (Cable et al., 2004).

W niniejszej pracy zbadano wpływ stwierdzonej rezydualnej strefy gazowej występującej poniżej konturu woda-gaz na proces produkcji z rzeczywistego złoża gazowo-kondensatowego. Analizy zostały wykonane za pomocą dynamicznego modelu złożowego z użyciem komercyjnego symulatora numerycznego Eclipse.

\section{Proces powstawania rezydualnego nasycenia gazem i jego mobilizacji}

Mechanizm powstawania rezydualnego nasycenia gazem, a następnie jego mobilizację, można podzielić na trzy etapy: drenaż pierwotny, wchłanianie (ang. imbibition) oraz drenaż wtórny wraz z ekspansją gazu (Undeland, 2012).

W celu dokładnego zrozumienia tego mechanizmu należy prześledzić od początku proces powstawania złoża gazowego. W warunkach początkowych, gdy złoże w całości nasycone jest wodą, w pewnym momencie następuje migracja gazu ze skały macierzystej do szczytu struktury skały zbiornikowej. Migrujący gaz stopniowo wypiera wodę z przestrzeni porowej, a na skutek różnicy gęstości następuje grawitacyjny rozdział fazy wodnej i gazowej. W strefie wypełnionej gazem zostaje jedynie niewielka ilość wody, tzw. woda związana, która zwilża hydrofilowe ziarna skały. Proces ten nazywany jest drenażem pierwotnym i przedstawiony jest schematycznie na rysunku 1a.

Następnie, na skutek różnego rodzaju czynników opisanych w dalszej części artykułu, może nastąpić dopływ wody z warstwy wodonośnej do strefy uprzednio wypełnionej gazem. Proces ten nazywany jest wchłanianiem - imbibition. Podczas dopływu wody część gazu zostaje uwięziona w przestrzeni porowej i staje się niemobilna. W ten sposób w obszarze, który został ponownie nasycony wodą, powstaje strefa rezydualnego nasycenia gazem (rys. 1b).

W trakcie eksploatacji w złożu dochodzi do obniżania ciśnienia, co powoduje ekspansję pęcherzyków uwięzionego gazu, które stopniowo zwiększają swoją objętość. Nasycenie gazem w przestrzeni porowej wzrasta, aż po pewnym czasie pęcherzyki gazu łączą się ze sobą, tworząc ścieżki migracji, i następuje ponowna mobilizacja fazy gazowej. Proces ten nazywany jest drenażem wtórnym (rys. 1c) (Egermann et al., 2009; Undeland, 2012).

\section{Rodzaje rezydualnej strefy nasycenia gazem}

Pochodzenie rezydualnej strefy nasycenia gazem może być antropogeniczne lub paleogeniczne. Antropogeniczna strefa rezydualna powstaje podczas eksploatacji złoża gazowego z aktywną warstwą wodonośną. W miarę spadku ciśnienia na skutek produkcji - następuje proces chłonności wymuszonej (forced imbibition), co prowadzi do przemieszczania się wody w kierunku złoża i podnoszenia kontaktu woda-gaz. Dodatkowo dopływająca woda wymusza przepływ dwufazowy w ośrodku porowatym, a tym samym zmniejsza przepuszczalność dla fazy gazowej. Powyżej pewnego nasycenia woda całkowicie blokuje ścieżki migracji dla gazu. Uwięziony gaz staje się niemobilny, dlatego nazywany jest z angielskiego residual lub trapped gas. a)

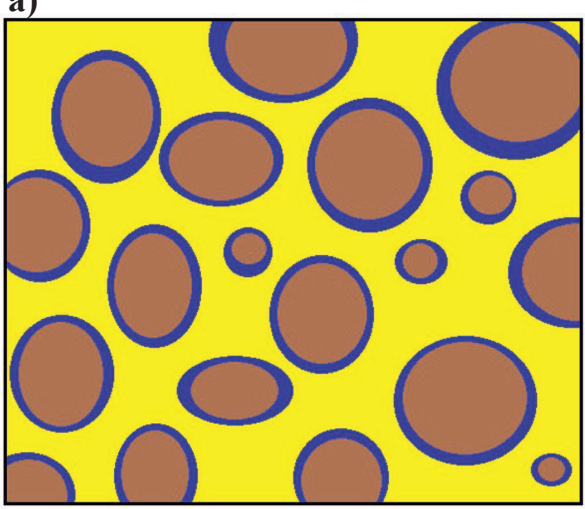

b)

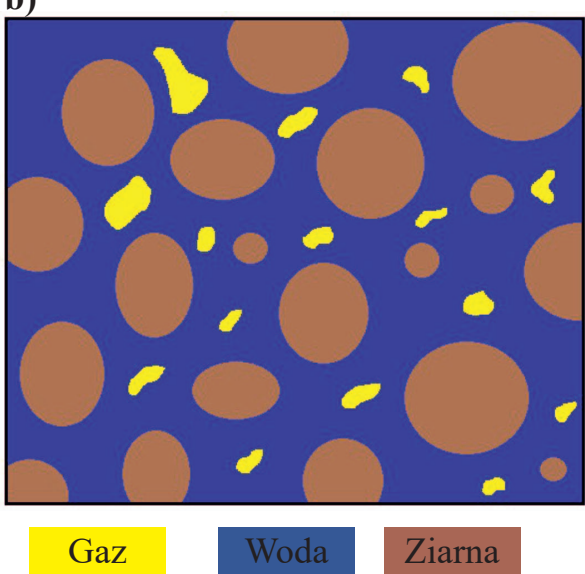

c)

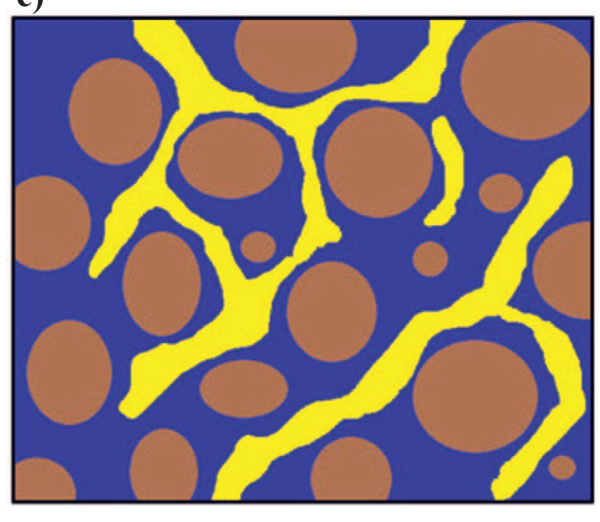

Rys. 1. a) Drenaż pierwotny, b) wchłanianie wody, c) drenaż wtórny

Fig. 1. a) Primary drainage, b) imbibition, c) secondary drainage 
Paleogeniczna strefa rezydualnego nasycenia gazem powstaje w przypadku, gdy w utworzonej geologicznie pułapce gazu na skutek różnego rodzaju czynników dochodzi do ustanowienia nowego, płytszego kontaktu woda-gaz. Przyczyną takiego procesu może być wtórna migracja gazu, na przykład na skutek aktywności tektonicznej. Mobilne węglowodory migrujące poza strukturę zastępowane są wodą złożową, co w konsekwencji prowadzi do podnoszenia kontaktu woda-gaz. Część gazu, która pozostała poniżej nowo ustanowionego konturu, tworzy rezydualną strefę nasycenia gazem. Taki stan rzeczy obserwowany jest $w$ wielu złożach węglowodorów na całym świecie. W niektórych przypadkach nasycenie węglowodorami poniżej konturu może sięgać nawet do $50 \%$, co może stanowić duży ułamek zasobów geologicznych (Cable et al., 2004). Przykład omawianego procesu przedstawiony jest schematycznie na rysunku 2. Złożem z paleogeniczną strefą rezydualnego nasycenia gazem jest np. złoże Ormen Lange, położone na norweskim szelfie kontynentalnym (Undeland, 2012). Nałożenie kilku czynników, takich jak sposób powstawania struktury, napełnianie pułapki gazem oraz różne etapy występowania anomalnego ciśnienia w basenie, doprowadziło do stopniowego podnoszenia kontaktu i ustanowienia go na obecnym poziomie. Dopływ wody do strefy, gdzie wcześniej znajdował się gaz, spowodował, że poniżej nowo ustanowionego kontaktu część gazu znajdującego się w przestrzeni porowej stała się niemobilna i utworzyła się strefa rezydualnego nasycenia gazem.

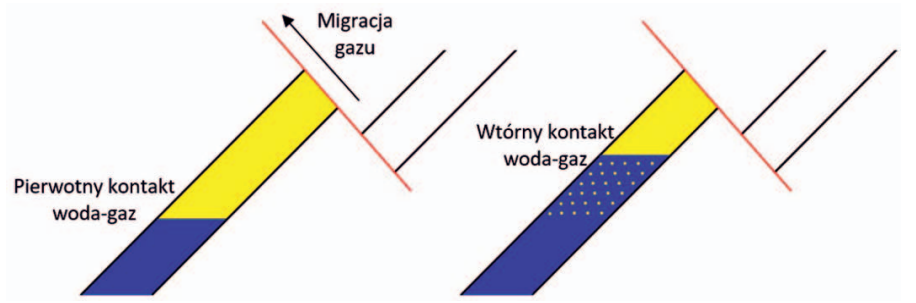

Rys. 2. Powstanie paleogenicznej strefy rezydualnego nasycenia gazem

Fig. 2. An illustration of formation of a paleo-residual zone

\section{Wpływ rezydualnego nasycenia gazem na eksploatacje}

Węglowodory występujące poniżej nowego konturu w początkowych warunkach złożowych, tj. ciśnienia oraz nasyceń, stanowią fazę niemobilną, stąd też często ich obecność jest nieuwzględniana podczas wykonywania analiz złożowych. Należy jednak pamiętać, że wraz ze spadkiem ciśnienia złożowego spowodowanym produkcją w złożu będzie dochodzić do ekspansji węglowodorów, a co za tym idzie - do zmiany nasyceń w przestrzeni porowej. W przypadku gazu ziemnego, którego ściśliwość jest wielokrotnie większa niż ropy naftowej, zmiana nasyceń w przestrzeni porowej może skutkować mobilizacją części uprzednio niemobilnego gazu występującego poniżej konturu woda-gaz, a tym samym dostarczyć dodatkowej energii oraz potencjalnie zwiększyć wydobycie ze złoża (Cable et al., 2004; Undeland, 2012). W niektórych przypadkach brak uwzględnienia rezydualnej strefy węglowodorów może prowadzić do błędnych wniosków na temat:

- zasobów geologicznych;

- zasobów wydobywalnych;

- wpływu aktywnej warstwy wodonośnej na bilans energetyczny złoża;

- liczby otworów potrzebnych do optymalnego sczerpania złoża.

$\mathrm{Z}$ uwagi na powyższe - rezydualne nasycenie przestrzeni porowej węglowodorami od lat jest przedmiotem badań wielu naukowców. Odgrywa ono kluczową rolę w oszacowaniu zasobów wydobywalnych, przede wszystkim w złożach z wodno-naporowym systemem energetycznym. Dopływ wody do złoża stanowi ważną przyczynę uwięzienia gazu w ośrodkach wodno-zwilżalnych, a jego ponowna mobilizacja niekiedy jest bardzo trudna do uzyskania. Mobilizacja i produkcja gazu ze strefy rezydualnego nasycenia zależy od rodzaju skały, komunikacji ciśnieniowej oraz natężenia dopływu wody z warstwy wodonośnej (Undeland, 2012).

Kantzas et al. (2000) oraz Ding i Kantzas (2004) w swoich pracach wykazują, że wartość rezydualnego nasycenia gazem nie jest łatwa do oszacowania i zależy od wielu czynników, m. in. właściwości zbiornika oraz płynów złożowych, liczby i rozmiarów porów, rozpuszczalności i ściśliwości gazu. Także sama metodyka przeprowadzania pomiarów oraz przygotowania rdzeni do badania ma znaczny wpływ na uzyskane wyniki i może prowadzić do skrajnie różnych rezultatów (Al-Arfaj et al., 2017). Do wiarygodnego określenia strefy rezydualnej i ilości gazu w niej zgromadzonego niezbędna jest ogromna ilość informacji, takich jak badania sejsmiczne i geofizyczne, pomiary rozkładu ciśnień w formacji, badania laboratoryjne, a przede wszystkim stwierdzenie nasyceń $\mathrm{w}$ otworze.

\section{Opis przedmiotu analizy}

Analizy zaprezentowane w niniejszej pracy zostały wykonane na złożu X. Złoże X jest gazowo-kondensatową akumulacją utworzoną w obrębie turbidytowych piaskowców kredowych. Skała zbiornikowa charakteryzuje się dobrymi parametrami złożowymi - porowatości mogą dochodzić do $25 \%$, natomiast przepuszczalności do kilkuset $\mathrm{mD}$. Z uwagi na stosunkowo niewielką wysokość kolumny węglowodorów złoże znajduje się głównie w strefie przejściowej, co skutkuje średnim nasyceniem wodą w strefie złożowej na poziomie kilkudziesięciu procent. Na strukturze wykonano kilka otworów poszukiwawczych oraz rozpoznawczych. Na podstawie pomiarów 
ciśnień RFT (z ang. Repeat Formation Test) został wyznaczony kontur woda-gaz (z ang. free water level). Analizy danych geofizycznych z otworów przechodzących przez strefę wodną wykazały, że poniżej zmierzonego konturu woda-gaz znajduje się strefa $\mathrm{z}$ rezydualnym nasyceniem gazem. Według pomiarów geofizyki otworowej w strefie rezydualnej występuje nasycenie gazem sięgające do $30 \%$. Powyższe obserwacje wskazują, że w przeszłości złoże posiadało głębszy kontur woda-gaz, a dolna część złoża została zawodniona poprzez napierającą warstwę wodonośną. Z uwagi na wiedzę oraz doświadczenie w rejonie, gdzie znajduje się złoże X, odrzuca się hipotezę o antropogenicznym pochodzeniu strefy rezydualnej. Złoże zagospodarowane jest przy wykorzystaniu horyzontalnych otworów produkcyjnych.

\section{Opis modelu dynamicznego oraz przyjęte założenia}

$\mathrm{Z}$ uwagi na wymiary geometryczne złoża X model symulacyjny nawet przy zastosowaniu stosunkowo dużego rozmiaru siatki symulacyjnej składał się z blisko 1 miliona komórek, co skutkowało długim czasem obliczeniowym. Po przeprowadzeniu niezbędnych testów zdecydowano o wykorzystaniu modelu black-oil zamiast modelu kompozycyjnego, co skutkowało przyspieszeniem procesu obliczeniowego (Fevang et al., 2000). Tym samym do analizy wykorzystano symulator złożowy Eclipse zamiast E300.

Model dynamiczny został zainicjowany nierównowagowo w celu odzwierciedlenia przestrzennej zmienności parametrów PVT stwierdzonej w otworach poszukiwawczych oraz rozpoznawczych. Z uwagi na nierównowagowy sposób inicjowania złoża konieczne było zdefiniowanie w formie tablic reprezentujących każdą komórkę modelu wartości takich parametrów jak: ciśnienie złożowe, nasycenie wodą złożową, nasycenie gazem, $R v$ lub $R s$.

Przepuszczalności fazowe w modelu reprezentowane są przez dwie znormalizowane krzywe przepuszczalności względnych woda-ropa oraz gaz-ropa, wykonane zgodnie z modelem LET (Lomeland, 2018) na podstawie badań laboratoryjnych. Rzeczone krzywe skalowane są w modelu dynamicznym z wykorzystaniem funkcjonalności end-point scaling (Petrofaq) w oparciu o wartości następujących parametrów: krytycznego nasycenia gazem, maksymalnego nasycenia gazem, krytycznego nasycenia wodą, minimalnego nasycenia wodą.

Wartości powyższych parametrów zostały opracowane na podstawie badań laboratoryjnych oraz zaimplementowane w formie tablic reprezentujących wartość każdej komórki modelu.

W modelu dynamicznym nie wykorzystano ciśnień kapilarnych z uwagi na fakt, iż początkowe nasycenie wodą złożową zostało zaimplementowane jako parametr wejściowy bezpośrednio z modelu statycznego, gdzie zostało wyznaczone na podstawie danych petrofizycznych.
W literaturze występują modele określające wartość nasycenia gazem w przestrzeni porowej po przejściu frontu wodnego (Suzanne et al., 2001). Wspomniane modele wykorzystują pomiary laboratoryjne i pozwalają na stworzenie zależności pomiędzy jakością skały zbiornikowej oraz rezydualnym nasyceniem gazem (Sgt - trapped gas saturation). Należy jednak pamiętać, że zmierzone laboratoryjnie wartości rezydualnego nasycenia gazem są obarczone dużą niepewnością (Suzanne et al., 2001). Dlatego też w poniższym studium zastosowano często wykorzystywaną w praktyce przemysłowej aproksymację, która zakłada, że rezydualne nasycenie gazem po przejściu frontu wodnego wynosi połowę początkowego nasycenia gazem.

W celu określenia wpływu strefy rezydualnej na proces eksploatacji złoża wykonano modele, w których założono występowanie rzeczonej strefy o stałej miąższości na całej rozciągłości złoża (rys. 3). Powyższe założenie wynika z obserwacji dokonanych w otworach poszukiwawczych oraz rozpoznawczych przechodzących przez warstwę wodonośną.
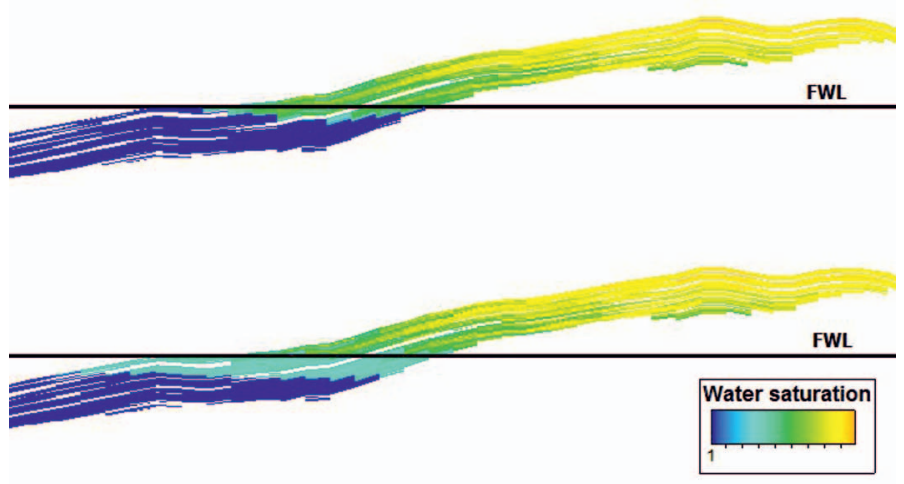

Rys. 3. Nasycenie wodą złożową w modelu dynamicznym bez uwzględnienia i z uwzględnieniem strefy rezydualnej

Fig. 3. Water saturation in simulation model, with and without paleo-residual zone

Aby zrozumieć wpływ strefy rezydualnej na wielkość wydobycia gazu ze złoża, przeprowadzono analizę wrażliwości z wykorzystaniem następujących parametrów:

- krytycznego nasycenia gazem w strefie rezydualnej;

- objętości warstwy wodonośnej.

Parametry te zostały wytypowane z uwagi na fakt, że mogą mieć bezpośredni wpływ na współczynnik sczerpania gazu ze strefy rezydualnej.

Na potrzeby analizy wykonano 6 modeli dynamicznych, spośród których 2 nie uwzględniają gazowej strefy rezydualnej, uwzględniają natomiast zmienne założenia dotyczące wielkości warstwy wodonośnej. W pozostałych czterech modelach została zdefiniowana rezydualna strefa nasycona gazem wraz ze zmiennymi założeniami wielkości aquifera oraz krytycznego nasycenia gazem w strefie rezydualnej. 


\section{Wyniki modelowania dynamicznego}

W celu zbadania wpływu rezydualnej strefy gazowej na proces eksploatacji dokonano porównania modeli z rzeczoną strefą względem modeli bez strefy przy konkretnych warunkach złożowo-produkcyjnych. Zmienność parametrów wykorzystanych do stworzenia modeli wraz z rezultatami zestawiono w tabeli 1.

Tabela 1. Zestawienie założeń i rezultatów modeli dynamicznych

Table 1. Summary of assumptions and results from dynamic models

\begin{tabular}{|c|c|c|c|c|c|c|}
\hline \multirow{3}{*}{ Model } & \multicolumn{3}{|c|}{ Parametry wykorzystane w modelach } & \multicolumn{3}{|c|}{ Rezultaty } \\
\hline & \multirow[t]{2}{*}{$\begin{array}{l}\text { objętość } \\
\text { aquifera }\end{array}$} & \multirow[t]{2}{*}{$\begin{array}{c}\text { strefa rezydualna } \\
\text { poniżej kontaktu } \\
\text { gaz-woda }\end{array}$} & \multirow[t]{2}{*}{$\begin{array}{l}\text { krytyczne nasycenie } \\
\text { gazem w strefie } \\
\text { rezydualnej }\end{array}$} & $\begin{array}{c}\text { zmiana } \\
\text { zasobów geolo- } \\
\text { gicznych gazu }\end{array}$ & $\begin{array}{c}\text { zmiana } \\
\text { skumulowanego } \\
\text { wydobycia gazu }\end{array}$ & $\begin{array}{c}\text { zmiana } \\
\text { skumulowanego } \\
\text { wydobycia wody } \\
\text { zlożowej }\end{array}$ \\
\hline & & & & \multicolumn{3}{|c|}{ [\%] } \\
\hline Base_1 & A & nie występuje & $\mathrm{N} / \mathrm{A}$ & $\mathrm{N} / \mathrm{A}$ & $\mathrm{N} / \mathrm{A}$ & $\mathrm{N} / \mathrm{A}$ \\
\hline Residual_1 & A & występuje & Sgcr $=$ Sgt & 19,11 & 5,79 & 110,18 \\
\hline Residual_SGCR_1 & A & występuje & $\mathrm{Sgcr}=\mathrm{Sgt}+5 \%$ & 19,11 & 0,27 & 164,63 \\
\hline Base_2 & $10 * \mathrm{~A}$ & nie występuje & N/A & N/A & N/A & N/A \\
\hline Residual_2 & $10 * \mathrm{~A}$ & występuje & Sgcr $=$ Sgt & 19,11 & $-4,27$ & 42,31 \\
\hline Residual_SGCR_2 & $10 * \mathrm{~A}$ & występuje & $\mathrm{Sgcr}=\mathrm{Sgt}+5 \%$ & 19,11 & $-1,28$ & 55,88 \\
\hline
\end{tabular}

A - początkowa objętość warstwy wodonośnej

Sgcr - krytyczne nasycenie gazem (najmniejsze nasycenie, przy którym gaz jest mobilny)

Sgt - nasycenie gazem po przejściu frontu wodnego ( $\mathrm{z}$ ang. trapped gas saturation)

- Zmiana skumulowanego wydobycia gazu względem wariantu Base_1

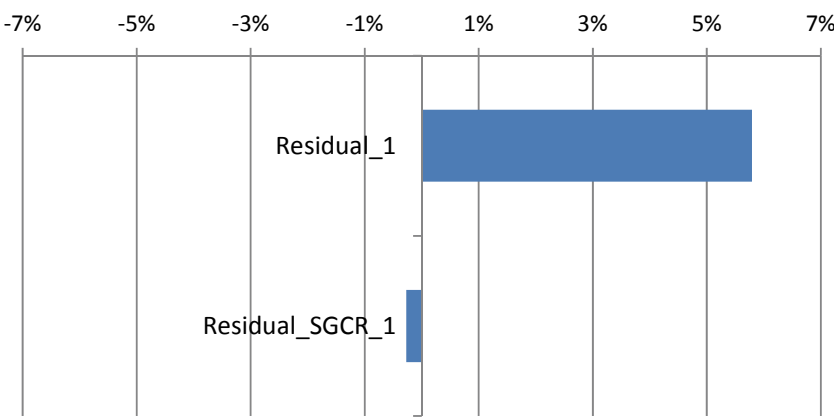

Rys. 4. Zmiana rezultatów symulacji w porównaniu do wariantu Base_1 - wydobycie gazu

Fig. 4. Change of simulation results against Base_1 case - cumulative gas production

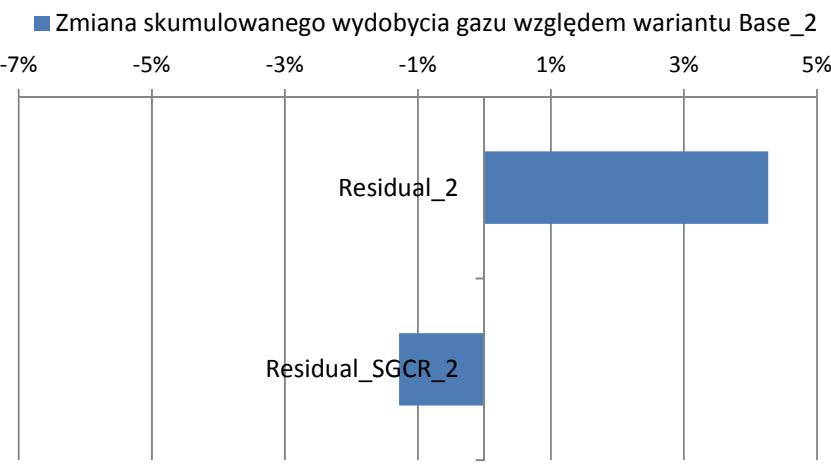

Rys. 6. Zmiana rezultatów symulacji w porównaniu do wariantu Base_2 - wydobycie gazu

Fig. 6. Change of simulation results against Base_2 case - cumulative gas production

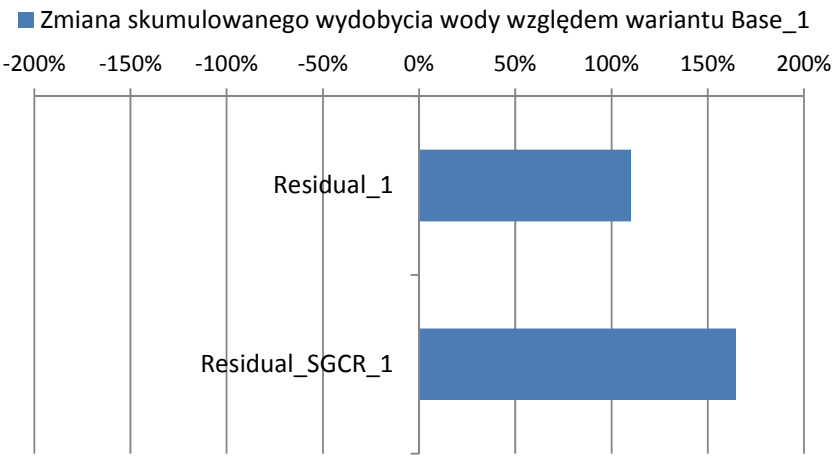

Rys. 5. Zmiana rezultatów symulacji w porównaniu do wariantu Base_1 - wydobycie wody

Fig. 5. Change of simulation results against Base_1 case - cumulative water production

- Zmiana skumulowanego wydobycia wody względem wariantu Base_2

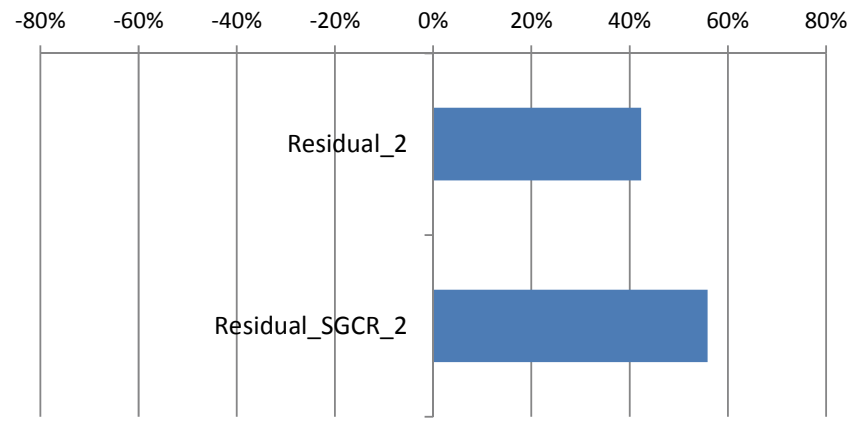

Rys. 7. Zmiana rezultatów symulacji w porównaniu do wariantu Base_2 - wydobycie wody

Fig. 7. Change of simulation results against Base_2 case - cumulative water production 
1. Po uwzględnieniu w modelu występowania strefy rezydualnej poniżej kontaktu gaz-woda zasoby geologiczne gazu wzrosły o $19,1 \%$.

2. Największy względny wzrost wydobycia, na poziomie 5,8\%, występuje, kiedy na złoże nie oddziałuje rozległy i aktywny aquifer oraz Sgcr $=$ Sgt (rys. 4).

3. W przypadku gdy Sgcr jest większe o 5\% w stosunku do Sgt, względne wydobycie gazu jest mniejsze niż w przypadku, kiedy Sgcr = Sgt, oraz mniejsze niż w przypadku niezakładania strefy rezydualnej (rys. 4, 6).

4. Uwzględnienie strefy rezydualnej skutkuje zwiększeniem względnego wydobycia wody złożowej we wszystkich analizowanych przypadkach (rys. 5, 7).

5. Występowanie strefy rezydualnej w przypadku, gdy złoże posiada wodnonaporowy system energetyczny oraz Sgcr $=$ Sgt $+5 \%$, może skutkować zmniejszeniem względnego wydobycia gazu (rys. 4, 6).

\section{Dyskusja na temat wyników}

W przypadku analizowanego złoża wielkość całkowitych zasobów geologicznych po uwzględnieniu strefy rezydualnej wzrosła o około 19\%. Tak duży wzrost wynika z faktu, że złoże ma dużą powierzchnię przy relatywnie niskiej wysokości kolumny węglowodorów. Wielkość wydobycia gazu ze strefy rezydualnej jest uzależniona od występujących warunków złożowo-produkcyjnych. W zależności od wspomnianych warunków strefa rezydualna może wpływać na wzrost lub redukcję wydobycia ze złoża. W przypadku złóż z wodno-naporowym systemem energetycznym wydobycie gazu ze strefy rezydualnej jest stosunkowo niewielkie. Wynika to $\mathrm{z}$ faktu, że w strefie rezydualnej nie dochodzi do znaczącego obniżenia ciśnienia, a tym samym niemobilny gaz nie może się wystarczająco rozprężyć i przekroczyć krytycznego nasycenia gazem umożliwiającego jego dalszy przepływ w stronę otworów produkcyjnych. Ponadto im mniejsza różnica pomiędzy krytycznym nasyceniem gazem a nasyceniem gazem w strefie rezydualnej, tym większy potencjał produkcyjny z rzeczonej strefy.

Otrzymane rezultaty wskazują również, że uwzględnienie rezydualnej strefy gazowej powoduje zwiększenie względnego skumulowanego wydobycia wody. W wykonanych modelach taki stan jest spowodowany poprzez dwa czynniki:

- wydłużenie w czasie profilu produkcji złoża;

- wcześniejsze zawodnienie otworów produkcyjnych.

Wydłużenie profilu produkcji związane jest z dodatkową energia złożową pochodzacą ze strefy rezydualnej. Energia ta pozwala na wyprodukowanie większej ilości gazu, czemu towarzyszy wzrost ilości wyprodukowanej wody złożowej.
Ilość dopływającej wody do złoża kontrolowana jest przez następujące czynniki wywołane ekspansją gazu:

- podtrzymanie ciśnienia w strefie rezydualnej;

- redukcję przepuszczalności fazowej wody.

W wykonanych modelach efekt redukcji przepuszczalności względnej wody był niewielki w porównaniu do efektu podtrzymania ciśnienia i nie zdołał ograniczyć dopływu wody ze strefy rezydualnej. Przełożyło się to na wcześniejsze zawodnienie odwiertów i zwiększenie skumulowanego wydobycia wody złożowej. Aby dokładniej zrozumieć to zjawisko i jego wpływ na rezultaty, konieczne byłoby wykonanie analizy wrażliwości z uwzględnieniem przepuszczalności względnej wody przy krytycznym nasyceniu gazem (krw(SGCR)).

W przeprowadzonej analizie nie zostało uwzględnione zjawisko rozpuszczalności gazu w wodzie złożowej, które przy obniżeniu ciśnienia mogłoby skutkować uwolnieniem dodatkowego gazu (Miłek et al., 2013). Takie założenie wynika z faktu, że oszacowana objętość gazu mogącego uwolnić się z wody złożowej w analizowanym przypadku stanowiła tylko $0,12 \%$ całkowitych zasobów geologicznych. W związku z tym ilość potencjalnie dodatkowego gazu rozpuszczonego w solance złożowej uznano za zaniedbywalną w analizie zagadnienia gazowej strefy rezydualnej.

\section{Wnioski}

Uwzględnienie strefy rezydualnego nasycenia gazem skutkuje wzrostem zasobów geologicznych, w analizowanym przykładzie nawet o 19\%, jednak potencjał produkcyjny tego interwału jest mniejszy niż głównej strefy złożowej. W efekcie zwiększone zasoby geologiczne nie przekładają się na proporcjonalny wzrost wydobycia gazu, który w przykładach numerycznych nie przekracza $6 \%$, a w szczególnych przypadkach może być nawet ujemny. Równocześnie obserwuje się zwiększone wydobycie wody.

Występowanie rezydualnej strefy gazowej może mieć pozytywny bądź negatywny wpływ na wielkość wydobycia gazu. Wielkość oraz rodzaj wpływu wynikającego z obecności strefy rezydualnej są bezpośrednio związane z warunkami geologiczno-złożowymi występującymi w danym złożu oraz z samym sposobem prowadzenia eksploatacji. Skutkuje to koniecznością indywidualnej analizy każdego przypadku w celu podjęcia decyzji czy w obliczeniach inżynierskich konieczne jest uwzględnienie strefy rezydualnej, czy też nie ma ona znaczącego wpływu na wyniki obliczeń. Wpływ strefy rezydualnej na proces produkcji powinien być analizowany zwłaszcza w przypadku złóż, w których strefa ta stanowi znaczną część całkowitych zasobów geologicznych - są to zazwyczaj złoża o dużej powierzchni i relatywnie niskiej wysokości kolumny 
węglowodorów. Przy znacznych zasobach gazu w strefie rezydualnej nawet kilkuprocentowy wzrost wydobycia może przełożyć się na spory zysk. W analizie ekonomicznej należy także uwzględnić zwiększenie wydobycia wody złożowej, co jednak w warunkach eksploatacji morskiej zazwyczaj nie stwarza dużego problemu i stanowi niewielki koszt.

\section{Literatura}

Al-Arfaj M., Al-Osail M., Sultan A., 2017. Monitoring imbibition of water into shale pore system: State of the art. Society of Petroleum Engineers. DOI: 10.2118/186904-MS.

Cable A., Mogford D., Wannell M., 2004. Mobilisation of trapped gas from below the gas-water contact. International Symposium of the Society of Core Analysts held in Abu Dhabi, UAE, 5-9 October, 2004.

Ding M., Kantzas A., 2004. Estimation of residual gas saturation from different reservoirs. Petroleum Society of Canada. DOI: 10.2118/2004-061.

Egermann P., Schaaf T., Brefort B., 2009. A Modified Hysteresis Relative Permeability Including a Gas Remobilization Threshold for Better Production Forecasts of Gas Storages. International Symposium of the Society of Core Analysts, Noordwijk. <https:// pascal-francis.inist.fr/vibad/index.php?action=getRecordDetail\&idt=23404946> (dostęp: 01.03.2020).

Fevang Ø., Singh K., Whitson C.H., 2000. Guidelines for choosing compositional and black-oil models for volatile oil and gascondensate reservoirs. Society of Petroleum Engineers. DOI: 10.2118/63087-MS.

Kantzas A., Ding M., Lee J., 2000. Residual Gas Saturation Revisited. Society of Petroleum Engineers. DOI: 10.2118/59782-MS.

Lomeland F., 2018. Overview of the LET Family of Versatile Correlations for Flow Functions. <https://www.researchgate. net/publication/327514600_Overview_of_the_LET_Family_ of_Versatile_Correlations_for_Flow_Functions $>$ (dostęp: 01.03.2020).

Miłek K., Szott W., Gołąbek A., 2013. Symulacyjne badanie procesów wypierania metanu rozpuszczonego w wodach złożowych poprzez zatłaczanie gazów kwaśnych w ramach ich sekwestracji. Nafta-Gaz, 2: 112-122.

Petrofaq. Saturation and relative permeability end-points scaling. $<$ http://petrofaq.org/wiki/Saturation_and_relative_permeability_end-points_scaling > (dostęp: 01.03.2020).

Suzanne K., Hamon G., Billiotte J., Trocmé V., 2001. Distribution of trapped gas saturation in heterogeneous sandstone reservoirs. International Symposium of the Society of Core Analysts, At-Edinburgh, United Kingdom.

Undeland E., 2012. Residual Gas Mobility in Ormen Lange. Norwegian University of Science and Technology, Department of Petroleum Engineering and Applied Geophysics.

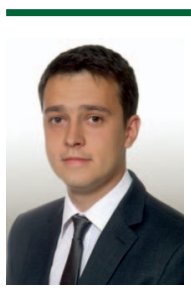

Tomasz TUCZYŃSKI

Inżynier złożowy

PGNiG UPSTREAM NORWAY AS

P.O. BOX 344, 4067 STAVANGER

VESTRE SVANHOLMEN 4, 4313 SANDNES

E-mail: tomasz.tuczynski@pgnig.no

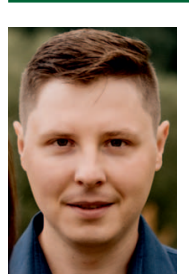

Daniel PODSOBIŃSKI

Inżynier złożowy

PGNiG SA Oddział Geologii i Eksploatacji

w Warszawie

ul. M. Kasprzaka 25

01-224 Warszawa

E-mail:daniel.podsobinski@pgnig.pl

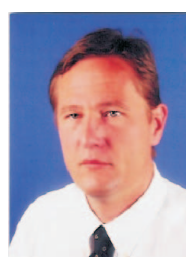

Prof. dr hab. inż. Jerzy STOPA

Profesor zwyczajny

Kierownik Katedry Inżynierii Naftowej

Akademia Górniczo-Hutnicza im. Stanisława

Staszica. Wydział Wiertnictwa, Nafty i Gazu

al. Mickiewicza 30, 30-059 Kraków

E-mail: stopa@agh.edu.pl 